\title{
Hubungan Kadar Gardiac Troponin T [CTnT] sebagai Penanda Jejas Miokardium dengan Derajat Pneumonia pada Anak
}

\author{
Meida Erimarisya, Heda Melinda Nataprawira, Nanan Sekarwana \\ Departemen Ilmu Kesehatan Anak Fakultas Kedokteran Universitas Padjadjaran/Rumah Sakit Dr. Hasan \\ Sadikin, Bandung
}

\begin{abstract}
Latar belakang. Hipoksemia berhubungan erat dengan pneumonia dan akan bertambah berat seiring bertambah beratnya pneumonia. Hipoksemia merupakan satu dari beberapa mekanisme yang menyebabkan komplikasi/penyulit kardiovaskular pada pneumonia. Cardiac troponin $\mathrm{T}$ (cTnT) telah digunakan secara luas sebagai penanda yang sensitif dan spesifik dalam deteksi kerusakan/jejas pada miokardium.

Tujuan. Menganalisis hubungan kadar cTnT sebagai penanda jejas miokardium dengan derajat pneumonia.

Metode. Penelitian cross-sectional dilaksanakan dari April-Juni 2013, dilibatkan 38 anak usia 2-60 bulan dengan diagnosis pneumonia dan dibagi dalam 2 kelompok, yaitu pneumonia dan pneumonia berat. Kadar cTnT serum dan pemeriksaan EKG dilakukan pada sedikitnya 72 jam awitan sesak. Analisis statistik dilakukan dengan uji Chi-kuadrat dan Mann-Whitney

Hasil. Kelompok pneumonia terdiri dari 17 subjek dan pneumonia berat 21 subjek. Rerata kadar cTnT masing-masing kelompok 10,33 pg/dL dan 17,51 pg/dL (p=0,037). Proporsi subjek dengan kadar cTnT $>10 \mathrm{pg} / \mathrm{mL}$ dalam kelompok pneumonia berat berbeda bermakna dibandingkan kelompok pneumonia $(\mathrm{p}=0,009)$. Kelainan gambaran EKG ditemukan pada 8 dari 20 subjek dengan kadar $\mathrm{cTnT}>10 \mathrm{pg} / \mathrm{mL}$ berupa gangguan irama, pemanjangan interval PR atau QT dan perubahan aksis jantung dan hipertrofi ventrikel kanan

Kesimpulan. Kadar cTnT berhubungan dengan derajat pneumonia. Peningkatan kadar cTnT menunjukkan kerusakan/ jejas non-iskemik pada miokardium. Sari Pediatri 2014;16(1):11-6.
\end{abstract}

Kata kunci: anak, cTnT, jejas miokardium, pneumonia

\footnotetext{
Alamat korespondensi:

Dr. Meida Erimarisya, SpA. Departemen Ilmu Kesehatan Anak Fakultas Kedokteran Universitas Padjadjaran/Rumah Sakit Dr. Hasan Sadikin, Bandung. Jl. Pasteur No. 38 Bandung 40163. E-mail: erimarisya@idai. or.id
}

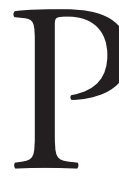

neumonia merupakan salah satu dari penyebab terbanyak kematian anak di seluruh dunia. World Health Organization (WHO) memperkirakan kasus pneumonia mencapai 150 juta per tahun dan sebagian besar (95\%) terjadi di negara berkembang. ${ }^{1,2}$ Di Indonesia, selama tahun 2011, dilaporkan kasus pneumonia pada anak sebanyak $480.000 .^{3}$ 
Hipoksemia pada pneumonia menyebabkan ketidakpadupadanan ventilasi perfusi yang akan menurunkan ketersediaan oksigen pada jaringan, termasuk jaringan miokardium. ${ }^{4-6}$ Kondisi ini menimbulkan beberapa perubahan metabolisme dalam kardiomiosit yang akan diikuti kerusakan/jejas pada sel. ${ }^{7,8}$ Pada anak dengan pneumonia, jejas miokardium telah dilaporkan dengan penanda enzim creatinine kinase $\mathrm{MB}(\mathrm{CKMB})^{9}$ dan pada anak dengan infeksi saluran nafas bawah yang disebabkan oleh Respiratory Syncytial Virus (RSV) dengan menggunakan cardiac troponin $\mathrm{T}$ (cTnT) sebagai penanda. ${ }^{10}$ Pemeriksaan cTnT telah digunakan secara luas sebagai penanda yang sensitif dan spesifik untuk deteksi merusakan jaringan miokardium (kualitatif) serta menggambarkan banyaknya jaringan yang mengalami kerusakan (kuantitatif). ${ }^{11,12}$

Penelitian ini bertujuan menganalisis hubungan kadar cTnT sebagai penanda jejas miokardium dengan derajat pneumonia.

\section{Metode}

Penelitian deskriptif analitik dengan rancangan potong lintang (cross sectional). Pengambilan sampel dilakukan secara consecutive hingga jumlah subjek terpenuhi. Subjek penelitian adalah anak usia 2-60 bulan yang menderita pneumonia dan dirawat di RS Hasan Sadikin. Anak dengan asma bronkiale, penyakit paru atau jantung bawaan, riwayat memerlukan ventilasi mekanik selama lebih dari 14 hari semasa neonatus, sepsis atau syok sepsis pada saat datang ke RS, keganasan dan/atau riwayat mendapat kemoterapi dan penyakit ginjal kronis dieksklusikan dari penelitian. Subjek dikelompokkan menjadi pneumonia dan pneumonia berat.

Pneumonia didefinisikan sebagai napas cepat menurut usia $(\geq 50 \mathrm{x} /$ menit untuk $2-11$ bulan atau $\geq 40 x /$ menit untuk 12-60 bulan) dengan crackles pada auskultasi paru dan didukung adanya infiltrat pada foto Rontgen thoraks. Pneumonia berat adalah pneumonia dengan distres napas berat (pernapasan cuping hidung, retraksi dalam dinding dada bagian bawah, head noddding, grunting, apnea intermiten atau memerlukan ventilasi mekanik), sianosis, kesulitan minum/ muntah, perubahan kesadaran dan gambaran kelainan yang berat pada foto Rontgen thoraks seperti infiltrat yang luas, konsolidasi, kolaps paru, efusi pleura atau empiema. Hipoksemia adalah saturasi oksigen $<90 \%$ yang diukur menggunakan pulse oximeter. Anemia adalah kadar hemoglobin $(\mathrm{Hb})<11 \mathrm{~g} / \mathrm{dL}$. Kadar cTnT dinyatakan dalam satuan $\mathrm{pg} / \mathrm{mL}$ yang diukur dengan metode assay menurut tes kuantitatif Roche Troponin T STAT (Elycsys and Cobas, Jerman) di laboratorium klinik Prodia Bandung dan disebut meningkat apabila $>10$ pg/mL. Kelainan gambaran EKG dikelompokkan menjadi gangguan irama, miokarditis, iskemi, dan RAD dan/atau RVH.

Uji chi-kuadrat digunakan untuk menganalisis faktor/ kondisi yang memengaruhi derajat pneumonia dan kejadian hipoksemia serta proporsi peningkatan cTnT pada tiap kelompok. Uji t-test digunakan untuk menganalisis hubungan antara rerata kadar $\mathrm{cTnT}$ dan derajat pneumonia.

\section{Hasil}

Subjek berjumlah 38 dan terdiri dari 17 subjek dalam kelompok pneumonia dan 21 subjek dalam kelompok pneumonia berat. Rerata usia subjek 7,78 (SB 7,47) bulan dengan rentang 2-40 bulan.

Beberapa faktor atau kondisi yang memengaruhi derajat pneumonia dan memperberat hipoksemia serta menimbulkan jejas/ kerusakan miokardium tertera pada Tabel 1. Tidak ditemukan perbedaan bermakna antara beberapa faktor yang memengaruhi derajat pneumonia atau anemia yang memengaruhi kejadian hipoksemia antara kelompok pneumonia dan pneumonia berat.

Rerata kadar cTnT untuk masing-masing kelompok dan perbedaan keduanya tertera pada Tabel 2 . Rerata kadar cTnT pada kelompok pneumonia berat lebih tinggi dan berbeda secara bermakna dengan kelompok pneumonia $(\mathrm{p}=0,037)$.

Perbedaan proporsi subjek pada kelompok pneumonia berat untuk mengalami jejas miokardium yang diidentifikasi dengan kadar cTnT $>10 \mathrm{pg} / \mathrm{mL}$ tertera pada Tabel 3. Uji chi-kuadrat ditunjukkan perbedaan bermakna $(\mathrm{p}=0,009)$ antara proporsi subjek pada kelompok pneumonia berat (15 dari 21) untuk mengalami jejas miokardium yang ditandai oleh cut-off point kadar cTnT $>10 \mathrm{pg} / \mathrm{mL}$ dibandingkan kelompok pneumonia (5 dari 17). Rasio prevalens menunjukkan bahwa pneumonia berat merupakan faktor risiko terjadinya peningkatan kadar cTnT, yakni anak dengan klinis pneumonia berat memiliki risiko 2,4 kali untuk mengalami jejas miokardium yang ditandai oleh kadar 
Tabel 1. Faktor/ kondisi yang memengaruhi derajat pneumonia dan hipoksemia

\begin{tabular}{|c|c|c|c|}
\hline \multirow[b]{2}{*}{ Karakteristik } & \multicolumn{2}{|c|}{ Kelompok } & \multirow[b]{2}{*}{ Nilai p' } \\
\hline & $\begin{array}{c}\text { Pneumonia } \\
(\mathrm{n}=17)\end{array}$ & $\begin{array}{l}\text { Pneumonia berat } \\
(\mathrm{n}=21)\end{array}$ & \\
\hline \multicolumn{4}{|l|}{ Usia } \\
\hline $\begin{array}{l}\text { Kurang dari atau sama } \\
\text { dengan } 1 \text { tahun }\end{array}$ & 15 & 17 & 0,553 \\
\hline Lebih dari 1 tahun & 2 & 4 & \\
\hline \multicolumn{4}{|l|}{ Imunisasi } \\
\hline Lengkap & 15 & 12 & 0,308 \\
\hline Tidak lengkap & 2 & 9 & \\
\hline \multicolumn{4}{|c|}{ Pengobatan dengan antibiotik sebelumnya } \\
\hline Ya & 11 & 15 & 0,460 \\
\hline Tidak & 6 & 6 & \\
\hline \multicolumn{4}{|l|}{ Status gizi } \\
\hline Normal & 15 & 14 & 0,120 \\
\hline Kurang & 2 & 7 & \\
\hline \multicolumn{4}{|l|}{ Saturasi oksigen } \\
\hline$<90 \%$ & 7 & 14 & 0,172 \\
\hline$>90 \%$ & 10 & 7 & \\
\hline \multicolumn{4}{|l|}{ Kadar $\mathrm{Hb}$} \\
\hline Anemia & 13 & 10 & 0,319 \\
\hline Tidak anemia & 6 & 9 & \\
\hline
\end{tabular}

*Uji chi-kuadrat

Tabel 2. Rerata kadar cTnT untuk kelompok pneumonia dan pneumonia berat

\begin{tabular}{lccc}
\hline \multirow{2}{*}{$\begin{array}{l}\text { Kadar cTnT } \\
(\mathrm{pg} / \mathrm{mL})\end{array}$} & \multicolumn{2}{c}{ Kelompok } & \multirow{2}{*}{ Nilai $\mathrm{p}^{*}$} \\
\cline { 2 - 3 } & $\begin{array}{c}\text { Pneumonia } \\
(\mathrm{n}=17)\end{array}$ & $\begin{array}{c}\text { Pneumonia berat } \\
(\mathrm{n}=21)\end{array}$ & \\
\hline Rerata $( \pm \mathrm{SB})$ & $17,51(12,71)$ & $10,33(11,02)$ & 0,037 \\
Median & 7,58 & 13,47 & 0 \\
\hline
\end{tabular}

*Uji Mann Whitney

Tabel 3. Hubungan kadar cTnT dan derajat pneumonia

\begin{tabular}{lccc}
\hline \multirow{2}{*}{ Kelompok } & \multicolumn{2}{c}{ Kadar cTnT $(\mathrm{pg} / \mathrm{mL})$} & \multirow{2}{*}{ Nilai $\mathrm{p}^{*}$} \\
\cline { 2 - 3 } & Meningkat $(>10)$ & Normal $(<10)$ & \\
Pneumonia berat $(\mathrm{n}=21)$ & 15 & 6 & 0,009 \\
Pneumonia $(\mathrm{n}=17)$ & 5 & 12 & \\
\hline
\end{tabular}

*Uji dengan chi-kuadrat

$\mathrm{c} \operatorname{Tn} \mathrm{T}>10 \mathrm{pg} / \mathrm{mL}$.

Gambaran EKG pada 20 subjek dengan kenaikan kadar c'TnT sebagai penanda jejas miokardium tertera pada Tabel 4.
Gambaran EKG abnormal didapatkan pada 8 dari 20 subjek dengan peningkatan kadar cTnT. Tidak satu pun subjek dengan peningkatan kadar c'TnT memberikan gambaran iskemi pada EKG. 
Meida Erimarisya dkk: Hubungan kadar cTnT sebagai penanda jejas miokardium dengan derajat pneumonia

Tabel 4. Gambaran EKG pada subjek dengan kadar cTnT meningkat

\begin{tabular}{lc}
\hline Gambaran EKG & $\begin{array}{c}\text { Jumlah } \\
(\mathrm{n}=20)\end{array}$ \\
\hline Normal & 12 \\
Aritmia & 1 \\
Iskemi & 0 \\
Miokarditis (pemanjangan interval PR, QT) & 3 \\
RAD, RVH & 4 \\
\hline
\end{tabular}

\section{Pembahasan}

Peningkatan kadar cTnT sebagai penanda yang sensitif dan spesifik untuk jejas miokardium didapatkan pada 20 dari 38 subjek. Hal tersebut tidak banyak berbeda dengan yang pernah dilaporkan sebelumnya oleh Ilten $\mathrm{dkk}^{9}$ yang menunjukkan peningkatan CKMB terjadi pada $68 \%$ subjek anak dengan pneumonia. Penelitian lain oleh Eisenhut $\mathrm{dkk}^{10}$ menunjukkan peningkatan kadar cTnT didapatkan pada 35\% anak dengan infeksi saluran nafas bawah oleh Respiratory Syncytial Virus (RSV). Pada penelitian ini didapatkan perbedaan antara proporsi subjek dalam kelompok pneumonia berat yang mengalami kenaikan kadar cTnT dibandingkan kelompok pneumonia. Secara umum, hipoksemia akan bertambah berat seiring perjalanan/klasifikasi pneumonia yang bertambah berat. ${ }^{13-15}$ Hipoksemia yang semakin berat akan menimbulkan jejas/ kerusakan yang lebih banyak pada jaringan miokardium. Hal tersebut ditunjukkan dengan hubungan antara kadar $\mathrm{CTnT}$ yang bertambah tinggi seiring bertambah beratnya derajat pneumonia.

Hipoksemia merupakan salah satu dari banyak mekanisme yang diduga melibatkan sistem kardiovaskular dalam perjalanan penyakit pneumonia. Pneumonia menyebabkan ketidakpadupadanan ventilasi perfusi yang menimbulkan berkurangnya kadar oksigen dalam darah (hipoksemia). ${ }^{4-6,9}$ Sebagai jaringan yang bersifat aerobik obligat, miokardium memerlukan ketersediaan oksigen yang cukup untuk menjalankan metabolisme secara normal. Hipoksemia secara langsung memengaruhi metabolisme dalam jaringan miokardium yang melalui berbagai mekanisme, seperti perubahan ekspresi gen miokardiosit, pembentukan oksida nitrit untuk mempertahankan tonus vaskular dan kontraktilitas jantung, serta disregulasi pembentukan spesies oksigen reaktif (SOR) yang dapat bereaksi langsung terhadap lapisan lipid, protein, dan DNA sel. ${ }^{7,8}$
Selain hipoksemia, ketidakseimbangan kebutuhan dan ketersediaan oksigen dalam jaringan miokardium turut diperberat oleh takikardia sebagai respons dari infeksi yang akan meningkatkan konsumsi oksigen. ${ }^{5}$

Hipoksemia dan hipoksia miokardium menimbulkan jejas/kerusakan miokardium yang ditunjukkan oleh peningkatan kadar cTnT. Jejas hipoksik ini diharapkan ditunjang oleh gambaran iskemia pada pemeriksaan EKG, tetapi pada penelitian ini tidak didapatkan subjek dengan peningkatan kadar cTnT yang menunjukkan gambaran iskemia pada pemeriksaan EKG. Keadaan ini menunjukkan bahwa hipoksemia bukan satu-satunya mekanisme keterlibatan jantung pada pneumonia, melainkan melalui proses yang kompleks dan belum sepenuhnya dapat dijelaskan hingga saat ini. Kerusakan/jejas non-iskemik dapat terjadi karena perubahan beban volume jantung, hiperaktifitas neurohormonal, dan miokarditis karena invasi kuman secara langsung atau akibat respons imun. ${ }^{4,5}$ Miokarditis ${ }^{9,10}$ dan hipertensi pulmonal ${ }^{16-18}$ dilaporkan sebagai penyulit kardiovaskular pada anak dengan pneumonia dalam beberapa penelitian terdahulu.

Pada penelitian ini didapatkan kelainan EKG pada 8 dari 20 subjek dengan kadar cTnT meningkat, berupa aritmia (eksrasistol ventrikel unifokal), pemanjangan interval PR dan QT yang menunjang gambaran miokarditis dan RAD atau RVH yang menunjang adanya hipertensi pulmonal. Miokarditis memiliki spektrum klinis yang luas sehingga sulit untuk didiagnosis. Baku emas diagnosis miokarditis dengan biopsi endomiokardium merupakan prosedur invasif sehingga sangat jarang dilakukan. Gejala klinis yang sangat bervariasi menjadikan kelainan gambaran EKG dan cut-off point kadar cTnT $>10 \mathrm{pg} / \mathrm{dL}$ merupakan modal yang penting dalam menegakkan diagnosis miokarditis ${ }^{19-21}$ dan penelitian ini menunjukkan kedua keadaan tersebut. Berbeda dengan dewasa yang menunjukkan gejala kardiak secara khas, mioakrditis pada anak memiliki gejala yang tidak spesifik dan bervariasi menurut umur. Gejala pada bayi dapat berupa demam, gelisah/rewel, poor feeding, apnea, sianosis, diaphoresis, bahkan berhubungan dengan kematian mendadak (sudden infant death syndrome atau SIDS), sedangkan pada anak yang lebih besar dapat menunjukkan gejala sesak nafas dan gejala intestinal (muntah, diare). Gejala ini tumpang tindih dengan gejala yang umum didapati pada anak dengan pneumonia, 
terlebih gambaran infiltrat interstisial, efusi pleura, dan kongesti vena paru pada gambaran Rontgen thoraks pneumonia juga mungkin didapatkan pada anak dengan mikarditis. ${ }^{20}$ Manifestasi klinis dan penunjang yang hampir serupa pada kedua keadaan tersebut digunakan sebagai kriteria diagnosis pneumonia pada penelitian ini sehingga pneumonia dan miokarditis sulit dibedakan dan saling tumpang tindih. Kejadian miokarditis baik berdiri sendiri atau sebagai penyulit pneumonia diduga jauh lebih tinggi dari yang telah dilaporkan. Freedman $\mathrm{dkk}^{22}$ melaporkan bahwa gejala terbanyak pada anak dengan miokarditis adalah gejala respiratorik dan $57 \%$ kasus didiagnosis sebagai pneumonia atau asma bronkiale pada saat pertama kali datang ke RS. Beberapa jenis virus dan bakteri tertentu diketahui bersifat kardiotropik dan berhubungan erat dengan kejadian miokarditis. Dengan kemungkinan infeksi virus yang sering dihubungkan dengan kejadian miokarditis dan identifikasi etiologi kuman pada subjek tidak dilakukan. Hal tersebut menjadi keterbatasan penelitian yang tidak dapat menjelaskan peningkatan kadar cTnT pada tiga subjek yang berusia muda (2 bulan) dengan tampilan klinis tidak berat, yang secara epidemiologis pneumonia pada kelompok usia ini lebih sering disebabkan oleh virus.

Gambaran RAD/RVH pada tiga subjek dapat terjadi baik karena miokarditis maupun hipertensi pulmonal. Perubahan aksis jantung ke arah kanan pada rekaman EKG telah dilaporkan pada anak dengan pneumonia dan perubahan ini berkorelasi dengan penurunan tekanan sistolik ventrikel kanan (right ventricular systolic pressure atau RVSP) pada pemeriksaan ekokardiografi. ${ }^{9}$ Keadaan serupa juga dilaporkan oleh Du dkk ${ }^{16}$ dan Uner $\mathrm{dkk}^{18}$ yang menunjukkan peningkatan tekanan arteri pulmonalis pada pemeriksaan ekokardiografi Doppler dan korelasinya terhadap derajat pneumonia. Hal tersebut tidak dapat dijelaskan pada penelitian ini karena tidak dilakukan pemeriksaan ekokardiografi.

Perubahan pada jantung terjadi sementara selama fase akut pneumonia, Ilten $\mathrm{dkk}^{9}$ melaporkan perubahan/perbaikan yang bermakna dari kelainan gambaran EKG dan ekokardiografi setelah 6 minggu masa akut pneumonia terlewati. Pemantauan memiliki arti penting dalam miokarditis, sebagian anak akan sembuh secara sempurna, sebagian berjalan menjadi kronis dan menyebabkan kardiomiopati dilatasi serta dapat meninggal.

\section{Kesimpulan}

Kadar cTnT sebagai penanda jejas miokardium berhubungan dengan derajat pneumonia pada anak. Pemeriksaan EKG menggambarkan jejas miokardium yang bersifat non-iskemi.

\section{Daftar pustaka}

1. Bryce J, Pinto C, Black R. WHO estimates of the causes of the deaths in children. Lancet 2005;365:1147-52.

2. WHO. Pneumonia the forgotten killer of children. World Health Organization, 2006. (Diakses 23 oktober 2009). Didapat dari: www.who.org.

3. Departemen Kesehatan Republik Indonesia. Profil kesehatan Indonesia. Jakarta: Depkes RI; 2011.

4. Corrales-Medina V, Musher D, Shachkina S, Chirinos J. Acute pneumonia and the cardiovascular system. Lancet 2013;381:496-505.

5. Corrales-Medina V, Suh K, Rose G, Chirinos J, Doucette $\mathrm{S}$, Cameron D, dkk. Cardiac complications in patients with community-acquired pneumonia: A systematic review and Meta-Analysis of observational studies. PLoS Med 2011;8:e1001048.

6. Musher D, Rueda A, Kaka A, Mapara S. The association between pneumococcal pneumonia and acute cardiac events. CID 2007;45:168-5.

7. Giordano F. Oxygen, oxidative stress, hypoxia, and heart failure. J Clin Invest 2005;115:500-8.

8. Suematsu N. Oxidative stress mediates tumor necrosis factor-alpha- indced mitochondrial DNA damage and dysfunction in cardiac myocytes. Circulation 2003; 107:1418-23.

9. Ilten F, Senocak F, Zorlu P, Tezic T. Cardiovascular changes in children with pneumonia. Turk J Pediatr 2003;45:306-10.

10. Eisenhut M, Sidaras D, Johnson R, Newland P, Thorburn $\mathrm{K}$. Cardiac troponin T levels and myocardial involvement in children with severe syncytial virus lung disease. Acta Paediatr 2004;93:887-90.

11. Babuin L. Troponin: the biomarker of choice for the detection of cardiac injury. CMAJ 2005;173:1191202.

12. Correale M, Nunno L, Ieva R, Rinaldi M, Maffei G, Magaldi R, dkk. troponin in newborns and pediatric patients. Cardiovasc Hematol Agents in Med Chem 2009;7:270-8.

13. Ayieko P, English M. In children aged 2-59 months 
with pneumonia, which clinical signs best predict hypoxaemia?. J Trop Ped 2006;52:307-10.

14. Basnet S, Adhikari R, Gurung C. Hypoxaemia in children with pnuemonia and its clinical predictors. Ind J Pediatr 2006;73:777-81.

15. Durbin W, Stille C. Pneumonia. Ped Rev 2008;29:14760.

16. Du J, Wang B, Li Y. Doppler echocardiographic evaluation of pulmonary artery pressure in pneumonia of infants and children. Pediatr Pulmonol 1991;10:2968.

17. Shann F, MacGregor D, Richens J, Coakley J. Cardiac failure in children with pneumonia in Papua New Guinea. Pediatr Infect Dis J 1998;17:1141-3.
18. Uner A, Caksen H, Arslan S, Abuhandan M, Oner A, Odabas D. Doppler echocardiographic evaluation of pulmonary artery pressure in children with acute pneumonia. Acta Paediatr Taiwan 2002;43:10-4.

19. Dancea A. Myocarditis in infants and children: a review for the pediatrician. Paediatr Child Health 2001;6:543-5.

20. Levine M, Klugman D, Teach S. Update on myocarditis in children. Curr Opin Pediatr 2010;22:278-83.

21. Uhl T. Viral myocarditis in children. crit Care Nurse 2008;28:42-63.

22. Freedman S, Haladyn J, Floh A, Joel A, Kirsch J, Taylor G. Pediatric myocarditis: Emergency department clinical findings and diagnostic evaluation. Pediatrics 2007;120:1278-85. 